\title{
PHYSICAL EDUCATION STUDY FIELD - IN SEARCH OF DISCIPLINARY IDENTITY
}

\author{
Edita VainienE் ${ }^{1}$, Giedré Judita Rastauskien. $\dot{2}^{2}$, Saulius Šukys ${ }^{1}$, \\ Asta LiLEIKIENE ${ }^{1}$ \\ ${ }^{1}$ Lithuanian Sports University, Kaunas, Lithuania \\ ${ }^{2}$ Kaunas College / University of Applied Sciences, Kaunas, Lithuania
}

\begin{abstract}
In order to understand meaningful landmarks for individuals and society, this article deals with the peculiarities of constructing disciplinary identity in the field of physical education. On the basis of the works for constructing identities in the physical education context we were trying to look for manifestations of disciplinary identity. Based on quantitative data gathered in Lithuanian universities, we have analysed the physical education study field from three directions: medicine and health, life sciences and education. In doing so, the provisions of the study participants interpreted by quantitative methods allowed us to distinguish four components of disciplinary identity: self-recognition, social recognition, satisfaction with the study field and objective communication. The analysis demonstrates essential differences regarding groups of study fields and the results suggest that undergraduate students from different study fields of physical education identify themselves differently and are acknowledged differently by their significant others. Hoping to encourage self-recognition and reduce differences in academic recognition of the physical education study field, students from the medical and health study field should be provided with the widest possible discourse of social sciences and the humanities. This is a way of helping students to become more self-aware as professionals and more capable of crossing boundaries of the physical education discipline.
\end{abstract}

Keywords: physical education, university studies, disciplinary identity, interdisciplinarity 


\section{INTRODUCTION}

Students who are graduates of a certain discipline can be recognized as specialists having their own professional practices and participating in social activities by means of language and cognitive methods characteristic of their respective discipline. Belonging together with other professional field representatives is due to their intellectual choice. Individuals are connected by a disciplinary identity - sense of one's place - socialized values, norms, expectations and behavioural modes acquired through experience and internalized in one's self [6]. But individuals can also solve scientific problems or issues without being a part of any higher education institution. This fact shows that they are more associated with certain science disciplines than with the institutions providing their studies $[14,25]$. It is becoming clear that the innate qualities of directing people to the practice of scientific disciplines, and the need to create and give a sense of identity itself, raises the question who am I?

Understanding of the question 'Who we are?' consists not only of personal, but also of social identity. The answer to the question 'Who am I?' is based on the reactions of others. Meaning arises through interaction with others, and individuality is created through self-reflection, when the unique part of the personality includes socially attributed definitions of others to an integral derivative [13]. The search for identity and desire for recognition are only meaningful if an individual pursues them deliberately. People whose lifestyle is specific (very religious, sexual orientation, distinct hobbies, idiosyncratic career imaginations, etc.) also fight for recognition and approval of their way of life [28].

The knowledge required for professional activities is achieved in many ways: in education and in practice (while studying is done); reflecting (reflection on what is being done and why); collaborating (when learning and teaching processes occur); pronounced passion (emotional involvement, when it is understood that the current activity is related to present and future purposes); acting for the whole community (the institution supports learning) [31]. The identity in physical education is related to their future occupation [20]. Sports experience as a certain cultural capital makes experience identity development processes at a rather young age. The academic world is a place that allows you to give meaning to the gained experience, developed physical characteristics and interests, as well as to establish identity [21,28]. In 2008 Lithuanian Ministry of Education and Science and 
academics decided to choose JACS ${ }^{1}$ for classification of academic subjects in Lithuanian universities. According to the Ministry of Government Order No. 1749 (Dec. 23, 2009) list of study areas and fields in which studies are offered in higher education institutions, physical education could be found in two study areas: biomedical sciences and social sciences. Lithuanian university studies of physical education can only be implemented as separate study fields: B300 rehabilitation (medicine and health group of study fields), C600 sport (life sciences group of study fields), and X100 pedagogy (education group of study fields). Within medicine and health group of study field, physical education can be taught as rehabilitation: kinesiotherapy, ergo therapy or applied physical activity. Within life sciences group, physical education can be taught as sport studies: training systems, body building, athletic education and rehabilitation, sport studies, sports biomechanics, movement learning and control, or sport psychology. Physical education can be also taught as physical education pedagogy within education group of study field.

Physical education uses physical activity to produce holistic improvements in a person's physical, mental and emotional qualities. Its core concern is the improvement of human movement and it is a broad field of interests [11]. We may safely state that some physical education issues cannot be solved by means of a single disciplinary approach. Physical education is not an academic discipline [10], it is rather sets of different disciplines from life sciences, health and medicine, and social sciences with their own different goals and practical application problems [15, 22]. Therefore, dimensions of why physical education students identify themselves more or less with one or another study field are not clear. In order to understand how the need for self-creation and giving meaning is satisfied in the field of physical education, we have to focus on the following questions: (1) To what extent are education models dictated by social environment significant for the construction of disciplinary identity?; and (2) To what extent is disciplinary identity geared to the satisfaction of individual needs? These problematic issues allow us to formulate the aim of the research - to reveal how the search for disciplinary identity is pursued in the study field of university physical education.

\footnotetext{
1 The Joint Academic Coding System (JACS) system is used by the Higher Education Statistics Agency (HESA) and the Universities and Colleges Admissions Service (UCAS) in the United Kingdom to classify academic subjects.
} 


\section{THEORETICAL STUDY ASSUMPTIONS}

The British higher education anthropologist Becher [2] in his theory of academic cultures claimed that disciplines can be defined as knowledge structures, which create different cultures in social life. This theory investigates the nature of knowledge, it is classified according to the Biglan [4] model, where the importance of discipline boundaries is emphasized (Table 1). Discipline - it is science areas - maximally objective, organized knowledge sets based on assumptions about the nature of knowledge, its development and compilation ways. The basis of epistemological proximity, disciplines often cluster into groups (or knowledge subsystems) such as: the natural sciences (e.g. physics, chemistry, biology), the social sciences (e.g. psychology, sociology, economics), the humanities (e.g. languages, music, visual arts), among others. Discipline, being an organized knowledge structure, creates a picture of the world where the not included objects, methods and concepts are removed. Different dimensions involve people in the knowledge acquisition process $[2,4,30]$.

Table 1. Classification of disciplines by Becher [2].

\begin{tabular}{lll}
\hline Ideal types & Nature of knowledge & Examples of disciplines \\
\hline Hard-pure & $\begin{array}{l}\text { Cumulative, atomistic, clearly defined by the } \\
\text { knowledge verification criteria, universal, } \\
\text { quantity-oriented, results presented in the form } \\
\text { of discovery. }\end{array}$ & $\begin{array}{l}\text { Astronomy, physics, } \\
\text { chemistry, mathematics, } \\
\text { economics, life sciences. }\end{array}$ \\
\hline Soft-pure & $\begin{array}{l}\text { Holistic systems are created, individuality } \\
\text { investigated, quality-oriented. Individualistic, } \\
\text { pluralistic, freely constructed, lack of consensus } \\
\text { in decision-making. }\end{array}$ & $\begin{array}{l}\text { History, linguistics, } \\
\text { philosophy, sociology. }\end{array}$ \\
\hline Hard-applied & $\begin{array}{l}\text { Consistent, targeted, practical, recognizes } \\
\text { both qualitative and quantitative access, } \\
\text { valued technical knowledge and the objectives } \\
\text { associated with the uptake of physical } \\
\text { environment and pragmatism. }\end{array}$ & $\begin{array}{l}\text { History of art, medicine, } \\
\text { engineering, forestry. }\end{array}$ \\
\hline Soft-applied & $\begin{array}{l}\text { Functional, utilitarian, iterative, more focused } \\
\text { on the operation of techniques than the } \\
\text { accumulation of knowledge, use of case studies. }\end{array}$ & $\begin{array}{l}\text { Education, politics, social } \\
\text { administration. }\end{array}$ \\
\hline & & \\
\hline
\end{tabular}

Disciplines are not just abstract structures. In reality they espouse as disciplinary communities having a recognizable identity (eg, lawyers, engineers, philosophers), based on cultural elements, such as traditions, customs, forms of activities, code of ethics, rules of behavior. The alliance of disciplinary communities is created due to a common intellectual choice, the 
cognitive techniques of reality, the vocabulary of the studied disciplines - an unambiguous awareness of symbolic and linguistic meanings, which allows freedom to communicate with each other.

Belonging to the disciplinary community may be aligned with belonging to the academic tribe. The identity of disciplinary community, as well as the identity of the tribe is defined only through its characteristic beliefs, experiences and practices. It is very important how strongly disciplinary community members adhere to the shared values, how deeply mastered is the discipline language (terms used in the discipline) and how much members of the community are committed to their recognized norms. The internal conflicts of disciplinary community members result due to the desire to dominate, but when the threats to the values of discipline arise members of the community become very united [23]. According to Bird [5], they fiercely defend their discipline area, patrolling the margins and are suspicious of those who try to change the established order. It has been pointed out that disciplines generally can be classified on the basis of the levels of consensus their members exhibit on such matters as appropriate theoretical orientations, proper research methods, and the relative importance of research questions. Highconsensus and strong paradigm development tend to characterize the physical sciences. Lower consensus and weaker paradigm development characterize the social sciences; and lowest consensus and paradigm development characterize the humanities (cited in [1]).

Looking from the perspective of academic cultures theory disciplinary boundaries may change both on the epistemic level and in the social life of communities. Disciplines can be represented as a geographical map of the world (map of disciplines). States may be near each other, while others far from each other. They can be separated by mountains, rivers and even oceans. This comparison is used to illustrate the convergence and divergence of disciplines. Convergence and divergence processes are exactly where disciplinary boundaries meet $[17,24]$, for example, in empirical methodology of science can be applied to the social disciplines. Limits of the disciplines are similar to physical walls of territories, however, they need to be understood as certain social interaction products [9]. For some countries urban culture is more common, while for other - rural culture. Urban cultural representatives tend to work in groups and communicate with each other or with others. Meanwhile, the rural cultural representatives often work individually, their communication is not so active. In terms of disciplines individual urban culture is dominant, but in the case of interdisciplinary interaction the nature of communication changes, because not so many disciplines can comprise other cultures such as physics or history [7]. 
In their bachelor level studies students typically specialize in one discipline. From the perspective of academic cultures theory the students - it is like tribal newcomers. They need to socialize on epistemic and social levels in order to be accepted into the tribe [26]. In the course of study, students continually identify their place in the disciplinary community. A better understanding of what is known, valued, appreciated, needs to be explored is being made. According to Ylijoki [30] approach, the socialization is based on moral order - virtues and vices, the basis of which loyalty to the discipline is created. The process involves the acquisition of certain disciplinespecific knowledge and methods as well as the acquisition of what Bourdieu [6] called the disciplinary habitus: representation of self identification with the discipline.

In the involvement in university studies, disciplinary identity takes on not only academic, but also the professional content [16]. Discipline works as community of practice as well. Performing one or the other practical activities of defined discipline, people become the participators of this discipline community. The context in which we live and where we work becomes very important, and being part of the community of practice leads to the identity of competence form [29]. The knowledge required for professional activities is achieved in many ways: in educational and practical activities (where studying is done); reflecting (reflection on what is being done and why); collaboration (when learning with others and going on mutual learning); onset of passion (emotionally engaging, understanding how the current activity is related to the present and future purposes); operation of the whole community (institutional structure supports learning) [31]. Students who will become professionals, it is important not only to develop skills to investigate problems rationally, to make decisions, to realize and understand why they are doing it focusing on solid evidence. Identity becomes stronger when we understand the meaning of our dependence and we decide who we are through a particularly complex interrelation of experience and participation in reflective projection [29]. It is not only the end result (as I perceive myself now), what characteristics define me (what is my identity), but also how I have become such as I am now.

According to the professional socialization theory of Weidman et al. [28], during the anticipatory stage of studies the student learns what is expected of him as a future specialist, what he needs to know and be able to do so that to work successfully in future. He begins to know the professional terminology, jargon and normative behavior. Professional communication takes place and is directed from teachers to students. Students are searching for their 
own path among the opportunities of the environment and actively seek to choose one of them. During the informal stage of the studies young people reflect the knowledge about learning environment, looking for information on regulatory standards, rewards and expect a positive feedback - seeking to understand what, how and why should be done. In this stage the student learns about the role of informal student characteristics. Plunging into the academic culture the students here watch acceptable behavior, communicate with peers and react accordingly - try to get to the disciplinary community of the chosen field of study. At this particular stage, students learn not to depart from academic standards of a particular discipline [30].

During the formal stage of studies expectations for selected studies is still idealized. Successful maintenance of formal examinations leads towards professional goals, and professional communication takes on a new character teachers and students cooperate together. Personal study phase involves the reflection of professional development. Depending on the self-assessment of personal characteristics: entrepreneurship, competitiveness and aggressiveness, students are studying less and feel more professionals. They try to reconcile the discrepancy between self-image and professional image - a small or big personality conflict is being solved. Up to this moment the problem of self-perception could be postponed, negative, ignored, rejected. Now it takes a sensory existence. At the end of the studies some mental meanings about themselves are acquired as a student of a whole field of study - a key individual's perception of the discipline associated with the need to give meaning to oneself as a professional. The further career decision is made after some searching, reflection and exploration of alternatives.

\section{MATERIALS AND METHODS}

\section{Participants and procedures}

During the studies, the identity of the different stages tends to change with the transitional stages of professional socialization consistently [28]. From a pragmatic point of view, the intention to continue studies is meaningful to examine in personal stage, so the sample of research were final year students - future bachelors. The research involved 419 fourth-year undergraduate students (48\% males and 52\% females) from universities in Lithuania: $37.9 \%$ in the study field of medicine and health, 35.6\% - life sciences and $26.5 \%$ - education (Table 2). This sample represents the Lithuanian physical education population of undergraduate students with $5 \%$ accuracy. 
Table 2. Characteristics of the study participants.

\begin{tabular}{lcccc}
\multicolumn{1}{c}{$\begin{array}{c}\text { Field and study } \\
\text { programmes }\end{array}$} & $\begin{array}{c}\text { Medicine and } \\
\text { health: } \\
\text { Physiotherapy, } \\
\text { Occupational } \\
\text { health, } \\
\text { Adapted } \\
\text { physical activity }\end{array}$ & $\begin{array}{c}\text { Life sciences: } \\
\text { Sports } \\
\text { coaching, } \\
\text { Health and } \\
\text { physical } \\
\text { activity }\end{array}$ & $\begin{array}{c}\text { Education: } \\
\text { Physical } \\
\text { education, } \\
\text { Physical } \\
\text { education and } \\
\text { dance }\end{array}$ & Total \\
University & 92 & 149 & 57 & 298 \\
\hline $\begin{array}{l}\text { Lithuanian Sports } \\
\text { University }\end{array}$ & $*$ & $*$ & 22 & 22 \\
\hline Šiauliai University & $*$ & $*$ & 32 & 32 \\
\hline $\begin{array}{l}\text { Lithuanian University of } \\
\text { Educational Sciences }\end{array}$ & 56 & $*$ & $*$ & 56 \\
\hline Lithuanian University of \\
Health Sciences
\end{tabular}

* Programmes in this study field are not provided by universities.

Theoretical framework has allowed the authors to develop a questionnaire survey with the statements reflecting the aim of the research (see Figure 1). The standardized psychometric test was not applied. The subjects expressing their preferences for each statement (see Figure 1) assessed them by ordinal scale, scoring them from 1 (completely disagree with the statement) to 4 (fully agree with the statement). The ordinal scale is positive; however, in a rating sense, it consists of both positive and negative values. To make it easier to understand what the statement evaluation is (positive or negative), the scale was standardized in the value interval from -1 to +1 . The weighted average $I$ was calculated for each statement. The closer the weighted average approximates to -1 or +1 , the more the subject agrees or disagrees with the statement.

\section{Data analysis}

Factor analysis was also applied to the collected data. The main factors were determined by the Varimax rotation method. The data suitability for factor analysis was calculated by the Kaiser-Meyer-Olkin (KMO) coefficient of sampling adequacy. Correlations lower than 0.5 were left out. The factor scale was considered consistent if the Cronbach's $\alpha$ coefficient was 0.5 or higher. The components distinguished in the factor analysis were named 
as dependent variables and set in quartiles. The study field was analysed as an independent variable. Cramer's $V$ coefficient was applied to evaluate the association between dependent and independent variables. The results were considered statistically reliable with a probability not higher than $5 \%$ $(p<0.05)$.

\section{RESULTS}

By studying the disciplinary identity of students from different groups of study field we analysed the clearly conceived knowledge of self and their understanding about identification with other members from the academic community as well as their understanding of the meaning of their profession and dispositions about interpersonal relationships within the academic community. The statements received greater approval from the subjects concerning their choice of study field and the significance of the profession, and fewer of them acceded to the statements concerning understanding of self as a student of the particular study field and interpersonal relationships within the academic community (Figure 1).

Table 3 shows that factorizing the collected data resulted in a four-factor matrix that had a common dispersion of $50.1 \%(K M O=0.85 ; p<0.01)$. The first component referred to the self-recognition component and had attributes 1-6 ascribed to it; the second one referred to the social recognition component and had attributes 7-10 ascribed to it; the third was the satisfaction with the study field component and it had attributes 11-15 ascribed to it; the fourth was objective communication and had attributes 16-20 ascribed to it. Factor analysis results and scale consistency are presented in Table 3. The factor analysis reveals nearly proportionate dispersion of the resulting components, and high Cronbach's $\alpha$ coefficients showed quite a high consistency of resulting factor scales. 


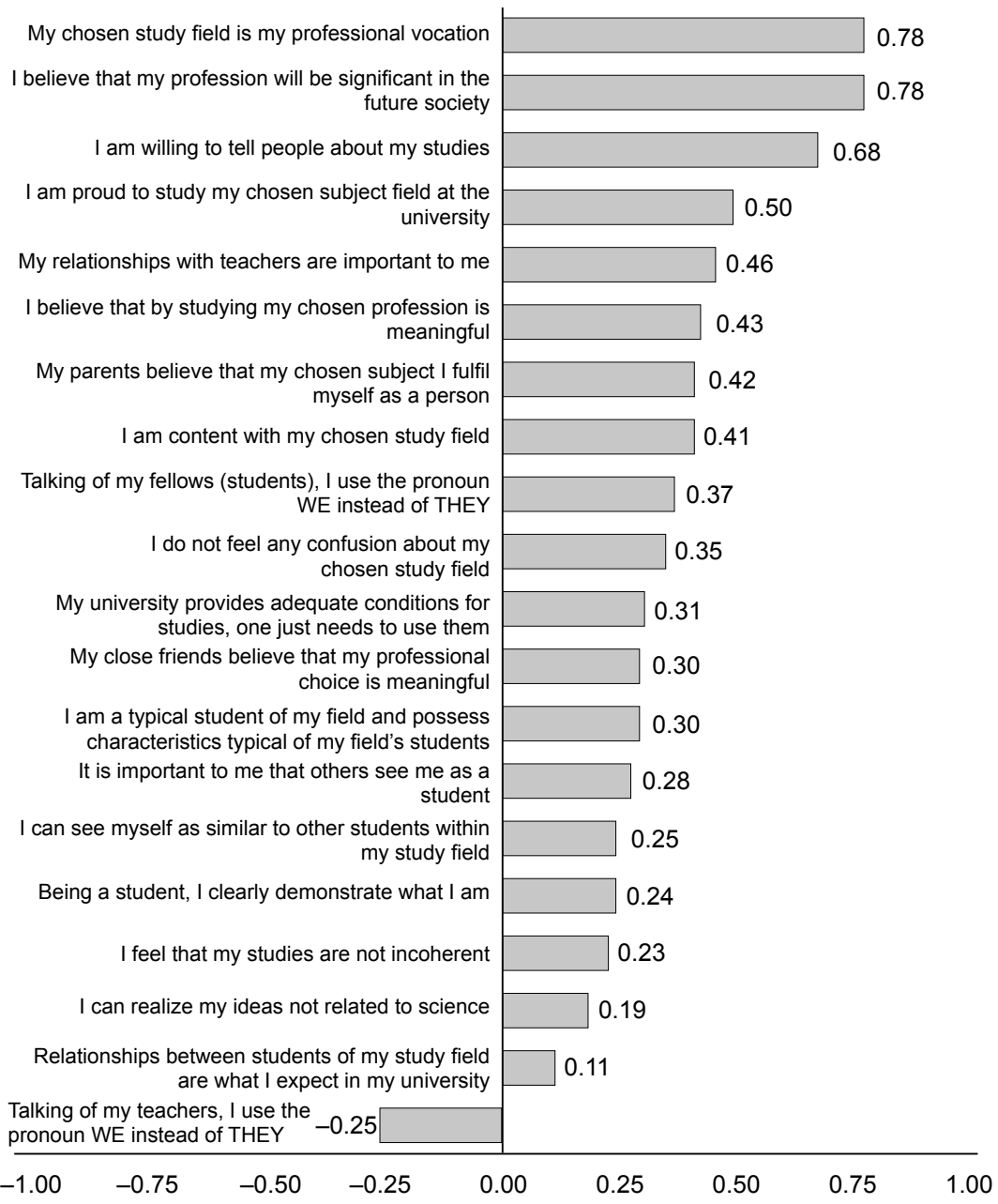

Figure 1. Distribution of weighted average $I(n=419)$. 
Table 3. Factor analysis results and scale internal consistency $(n=419)$.

\begin{tabular}{|c|c|c|c|c|}
\hline \multirow[b]{2}{*}{ Attributes } & \multicolumn{4}{|c|}{ Components } \\
\hline & $\begin{array}{l}\text { Self-rec- } \\
\text { ognition }\end{array}$ & $\begin{array}{l}\text { Social rec- } \\
\text { ognition }\end{array}$ & $\begin{array}{l}\text { Satisfaction } \\
\text { with the } \\
\text { study field }\end{array}$ & $\begin{array}{l}\text { Objective } \\
\text { communi- } \\
\text { cation }\end{array}$ \\
\hline $\begin{array}{l}\text { Being a student, I clearly demon- } \\
\text { strate what I am }\end{array}$ & 0.74 & & & \\
\hline $\begin{array}{l}\text { It is important to me that others see } \\
\text { me as a student }\end{array}$ & 0.71 & & & \\
\hline $\begin{array}{l}\text { I am a typical student of my field and } \\
\text { possess characteristics typical of my } \\
\text { field's students }\end{array}$ & 0.63 & & & \\
\hline $\begin{array}{l}\text { Talking of my fellows (students), I } \\
\text { use the pronoun We instead of They }\end{array}$ & 0.60 & & & \\
\hline $\begin{array}{l}\text { I believe that by studying my chosen } \\
\text { subject I fulfil myself as a person }\end{array}$ & 0.58 & & & \\
\hline $\begin{array}{l}\text { I can see myself as similar to other } \\
\text { students within my study field }\end{array}$ & 0.56 & & & \\
\hline $\begin{array}{l}\text { My close friends believe that my } \\
\text { professional choice is meaningful }\end{array}$ & & 0.76 & & \\
\hline $\begin{array}{l}\text { My parents believe that my chosen } \\
\text { profession is meaningful }\end{array}$ & & 0.75 & & \\
\hline $\begin{array}{l}\text { I believe that my profession will be } \\
\text { significant in the future society }\end{array}$ & & 0.67 & & \\
\hline $\begin{array}{l}\text { I am willing to tell people about my } \\
\text { studies }\end{array}$ & & 0.48 & & \\
\hline $\begin{array}{l}\text { I can realize my ideas not related to } \\
\text { science }\end{array}$ & & & 0.74 & \\
\hline $\begin{array}{l}\text { I feel that my studies are not } \\
\text { incoherent }\end{array}$ & & & 0.67 & \\
\hline $\begin{array}{l}\text { I do not feel any confusion about my } \\
\text { chosen study field }\end{array}$ & & & 0.66 & \\
\hline $\begin{array}{l}\text { I am content with my chosen study } \\
\text { field }\end{array}$ & & & 0.56 & \\
\hline $\begin{array}{l}\text { My chosen study field is my } \\
\text { professional vocation }\end{array}$ & & & 0.48 & \\
\hline $\begin{array}{l}\text { Relationships between students of } \\
\text { my study field are what I expect in } \\
\text { my university }\end{array}$ & & & & 0.72 \\
\hline $\begin{array}{l}\text { Talking of my teachers, I use the } \\
\text { pronoun We instead of They }\end{array}$ & & & & 0.57 \\
\hline $\begin{array}{l}\text { My university provides adequate } \\
\text { conditions for studies, one just } \\
\text { needs to use them }\end{array}$ & & & & 0.56 \\
\hline $\begin{array}{l}\text { My relationships with teachers are } \\
\text { important to me }\end{array}$ & & & & 0.49 \\
\hline $\begin{array}{l}\text { I am proud to study my chosen } \\
\text { subject field at the university }\end{array}$ & & & & 0.451 \\
\hline Component dispersion, $\%$ & 15.20 & 14.10 & 11.40 & 9.40 \\
\hline $\begin{array}{l}\text { Scale internal consistency coefficient } \\
\text { Cronbach's } \alpha\end{array}$ & 0.78 & 0.74 & 0.73 & 0.6 \\
\hline
\end{tabular}


Analysis of associations between components and study fields reveals that the self-recognition component for students of life sciences as well as medicine and health sciences was statistically less important than for students from the education study field ( $V=0.18 ; p=0.02)$ (Figure 2). There are also noticeable differences in the social recognition component between different study fields of physical education $(V=0.29 ; p=0.001)$. The social recognition component for students of medicine and health sciences was higher than for students of life sciences or students from the physical education study field (Figure 3). The research reveals no noticeable difference in the satisfaction with the study field and objective communication components (Figures 4 and 5).

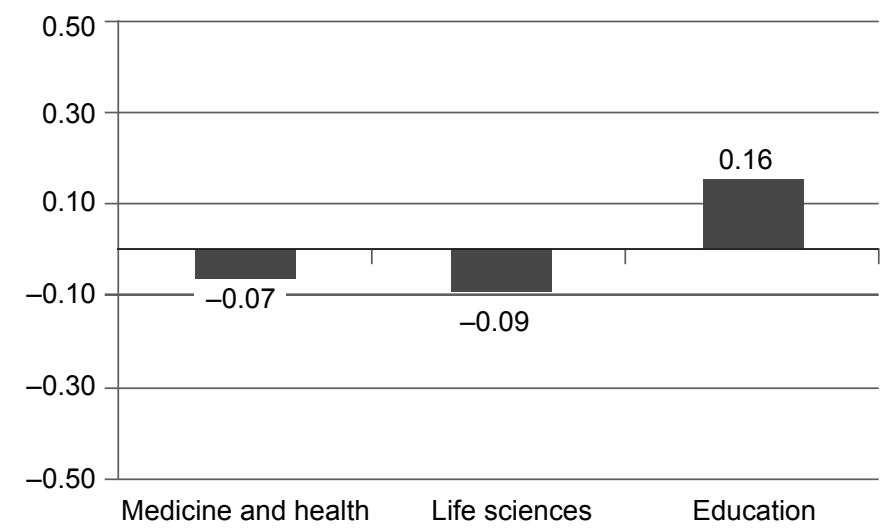

Figure 2. Weighted average of the self-recognition component $(n=419)$.

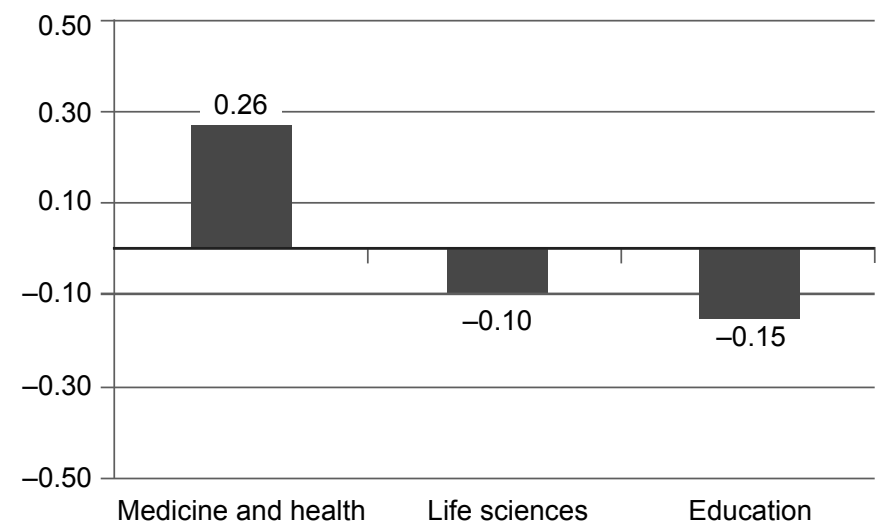

Figure 3. Weighted average of the social recognition component $(n=419)$. 


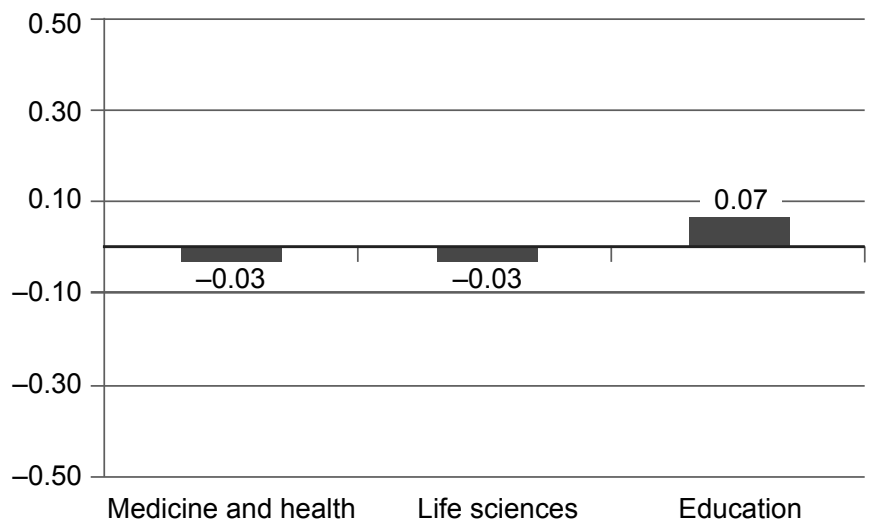

Figure 4. Weighted average of the satisfaction with the study field component $(n=419)$.

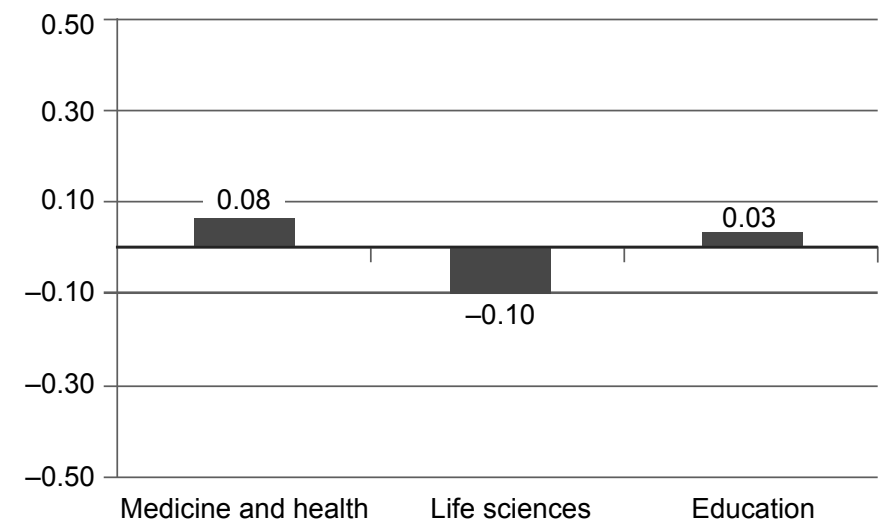

Figure 5. Weighted average of the objective communication component $(n=419)$.

The results obtained suggest that physical education undergraduates expect to provide society with professional services and adjust their self-concept to the requirements of their significant others and the academic community. However, students from different study fields of physical education identify themselves differently and are recognized and supported by their significant others in different ways. 


\section{DISCUSSION}

Young people usually tend to have preconceptions about studies at university. While still at school, would-be students form expectations that physical education studies would provide them with a career, and the knowledge and skills they acquire would prove useful. The more education preconception and education reality have in common, the fewer doubts there are about the chosen study field. The study suggests that four-fifths of the subjects claim their study field to be their vocation, and that the acquired competencies will be useful for the society in the future. Three-quarters of them are proud of the chosen study field. Relationships with their teachers are of great importance. The gap between expectations and the reality of the studies is not big.

At the final stage of study the reflection on the meaning of studies as well as on professional development takes place. This is a critical stage of human life - undergraduate studies are coming to an end and one needs to answer the question Who am I? In our research, statements on disciplinary identity and evaluation of interpersonal relationships received a lower approval. Two-thirds of the students surveyed feel no confusion about their chosen field of study: they clearly show who they are and see their similarity with other students from their chosen study field. Half of the subjects said that they could implement ideas unrelated to science. Low assessment of students' interpersonal relationships, and negative identification between students and teachers in the categories of We and They, show that the objective communication in the final study phase is disturbed. Among the surveyed study fields there is no statistically significant difference - results show that in all study fields professional language interference inhibits disciplinary uniqueness. The field of sports is one of the most problematic here. It requires not only knowledge, but also the technical skills that begin to develop in childhood or early youth. Knowledge of professional language and subject literature within each field is essential in order to achieve mutual understanding [2]. Discipline should provide students not only with the necessary cognitive milestones, but also with a clear discipline-specific terminology. Learning discipline-specific vocabulary and technical terms is as important as learning methods, procedures and concepts (in fact, the latter cannot be learned without learning discipline-specific terminology).

Statistical analysis allowed us to identify the four most important components: self-recognition, social recognition, satisfaction with the study field and objective communication. Self-recognition includes such features as clearly perceiving oneself as a typical representative of the study field, selfrealization, commonality and similarity to other students in this field. Social 
recognition involves the perception that the choice of study field is meaningful for one's own self and also for significant others (friends, parents, the future of the public). Satisfaction with the study field includes the understanding that there is no confusion concerning the choice of study field. It is a vocation and an opportunity to materialize not only science-related ideas. Objective communication includes pride in university studies and knowledge that study conditions are quite good, relations between students are what they have been expected to be, and identification with teachers and peer relationships are rather significant.

Self-recognition is a deliberate, reflective and socially responsible awareness of one's own identity. It embodies integration - the feeling that I am whole, not fragmented - and commonality - the perception that I am similar to others. It is not only important how clearly I perceive myself, but how I see myself. Students from different study fields perceive themselves in a different way. Undergraduates of the physical education (pedagogy) study field, more than their colleagues from the study fields of medicine and health, as well as life studies, clearly show their dependence on the academic environment; there is a strong conviction that they have features characteristic of their field of study, they put greater emphasis on mutual similarity, and when communicating, frequently use the pronoun We, not They. In addition, it is important that people around them perceive them as students of a particular area of physical education - the future physical education teachers.

Recognition is the value that is assigned to an individual by significant others (how I am valued by others). It describes what people approve of, support and encourage. Recognition is a necessary condition for a meaningful life. It is acquired in specific contexts only for specific good qualities, skills or works [27]. Significant others are the most important people in the personal social environment, but we can also talk about the imagined, believed or passed-away individuals or their groups. They approve or disapprove of the achieved positions and assumed social roles. Where we fail to safely lean on the closest people's reactions, generally perceived "meaning of the world" is slowly disappearing, and the identity formation as well as the creation of meaning is becoming problematic. According to Wagner [27], social recognition is important for identitying formation since it is basically necessary for an individual to build self-confidence without which we can have neither the concept of a meaningful life nor its realization.

Recognition does not necessarily coincide with the recognized (realized) value of identity. Although physical education pedagogy undergraduates perceive themselves as students more clearly, students from the medicine 
and health study field get more support from their families and friends about students' choice of study field, and those students are more eager to talk about their studies than students from the life sciences or physical education pedagogy study fields. All the study fields under investigation possess psychologically safe and meaningful professional features because all of them have moved from a vocational to an academic model [11]. They are associated with health, health enhancement, and the formation and development of healthy lifestyle skills. However, there is a significant difference with regard to areas of study fields.

University physical education studies can be directed at body improvement techniques (body appearance improvement or participation in sports contests), post-trauma rehabilitation, deferring of death or improving quality of life. In one instance, the aim is improved movement - to achieve faster reaction, higher strength or speed; in another, it is health enhancement and rehabilitation; in the third, movement is understood as physical activity providing an opportunity for a long, fully fledged life. When the aim is directed at movement and its improvement techniques, new fundamental knowledge is provided that is aimed at finding out how the human body works (interest in the human body as an object), and the results allow us to create prognostication theories. Such studies can be described as academic profile studies. They have tended to be disciplinary studies, which resulted in sciencebased professions. However, when the focus is on the impact of movement on dynamic social systems, no long-term prognostication theories can be defined. Those studies integrate the contents of different sciences, such as medicine, health, social and life, and they aim at the configuration of creative knowledge and applying it to the society's needs (interest in the human body being as a subject). These profile studies have tended to be multidisciplinary studies, which resulted in social professions. The difference in profiles may presuppose real or imaginary disciplinary inequality.

Single-disciplinary profile students have one essential strategy of committing to the disciplinary community - maintaining loyalty for their physical education study field paradigm and its basic disciplinary ethos [2]. In contrast, students of multidisciplinary profile studies are allowed to choose between different strategies of commitment to the chosen study field. It is easier for them to overcome some invisible boundaries between "own" and "alien" disciplines [4]. For instance, in the nursing discipline, we can discern three commitment strategies used by students. Some of them associate themselves with academic medicine disciplines; others attempt to find an interdisciplinary approach to nursing; and the third group distance them- 
selves from academic or professional aspects of nursing and participate in nursing administration or control processes [18].

Although it is easier for physical education pedagogy students to draw the outline of the student's self, academic recognition is not felt because of linking their studies with a seemingly useless profile. Life and physical education pedagogy students are less willing to tell others what they are studying than students from the medicine and health study field. Their belief in the meaningfulness of their profession is weaker. If studies do not provide sufficient epistemological insight [3], physical education students cannot defend their status [8]. Perception of one's own self as a professional of the particular area requires intellectual effort. In order to gain a sense of being an integral, rather than fragmented personality, it is necessary to study anatomy, chemistry, physiology, physics, statistics, history, psychology, anthropology and sociology. However, the acquired multidisciplinary status leads one to doubt oneself and teaches one to assume extreme behaviours (withdrawal, passivity, aggression, destruction). Only mature people can lean on their experience, clear convictions or a firm belief. Without social recognition it would be hard enough to keep their identity. Striving and persistent individuals reduce, and perhaps even transform, non-recognition into positive things. However, the others end in failure. They remain without meaningful life landmarks [27].

\section{CONCLUSIONS}

The main purpose of this paper has been explaining discipline identity in the physical education study field at individual and social level. On the basis of the works for constructing identities in the context of the disciplinary identity was defined as the framework of mental meanings about self - a conscious structure of knowledge, emotions and self-evaluations about self as a future professional in a particular study field. In the analysis performed, four students' interdisciplinary identity components were distinguished: selfrecognition, social recognition, satisfaction with the study field and objective communication. The individual stage of disciplinary identity includes two components: self-recognition and satisfaction with the study field. Here the meaning is found in reference to the vocation concept and belief (expectation) that the acquired knowledge will be needed for the future society. At this stage, physical education pedagogy students have fewer problems in recognizing themselves as typical individuals in their chosen study field. It is easiest for them of all three surveyed study fields to draw the framework 
of the student's self. The social identity disciplinary stage includes social recognition and objective communication components. Significant environment for the individual is more supportive for the students of the medicine and health study field (the medical and health study field is recognized as more meaningful by significant others than the life sciences and physical education pedagogy study fields). However, linking oneself with a multidisciplinary study profile, recognition has not been felt. This has an adverse impact on an individual's expectations in the future to provide professional services for the public. Commonality-based communication with students and teachers of the particular field is problematic in all three study fields. Students' objective communication, even in the final stage of studies, remains disturbed due to ambiguous interest in the human body (as an object or as a subject) perception. The latter implies the quality of the acquired knowledge and skills. Here, the mark of identity becomes professional vocabulary (subject-language), and its analysis - a landmark for further research of physical education students' identity.

Constructing identity in the present means continuing what was in the past and looking at what you are going to be in the future. Hoping to encourage the recognition of self and reduce differences in academic recognition of the physical education study fields, universities should take responsibility in providing students of the medicine and health study fields with a broader discourse of social sciences and humanities, which includes the origins, history and philosophy of physical education. The idea of future higher education is a creative configuration of heterogeneous knowledge and its application to the needs of society [12]. Only going this way is it possible to create the type of disciplinary identity that becomes recognizable and covers a broad perspective.

\section{REFERENCES}

1. Austin AE. (1996) Institutional and departmental cultures: The relationship between teaching and research. New Directions for Institutional Research, 90: $57-66$

2. Becher T. (1989) Academic tribes and territories: Intellectual enquiry and the cultures of disciplines. Milton Keynes, England: Open University Press

3. Beelby FL. (2000) The validation of a model of the structure of knowledge for the field of physical education. PhD, Texas Tech University

4. Biglan A. (1973) The characteristics of subject matter in different academic areas. J Applied Psych, 57 (3): 195-203 
5. Bird E. (2001). Disciplining the interdisciplinary: Radicalism and the academic curriculum. BJSE, 22 (4): 463-478

6. Bourdieu P. (1989) Social space and symbolic power. JSTOR, 7 (1): 14-25

7. Bradbeer J. (1999) Barriers to interdisciplinarity: Disciplinary discourses and student learning. Journal of Geography in Higher Education, 23 (3): 381-396

8. Brooks GA. (1981) Perspectives on the academic discipline of physical education. Champaign: Human Kinetics

9. Dölling I, Hark S. (2000) She who speaks shadow speaks truth: Transdisciplinarity in women's and gender studies. Signs, 25 (4): 1195-1198

10. Filho RAR. (2000) In search of academic identity: Physical education, sport science and the field of human movement Studies. PhD, The University of Leeds. School of Education. Centre for Studies in Physical Education and Sport Science

11. Freeman WH. (2011) Physical education, exercise and sport science in a changing society. 7th ed. Massachusetts: Jones \& Bartlett Publishers

12. Gibbons M, Limoges C, Nowotny H, Schwartzman S. and Trow, M. (1994) The new production of knowledge: The dynamics of science and research in contemporary societies. Sage Publications

13. Giddens A. (1991) Modernity and self-identity: Self and society in the late modern age. Cambridge: Polity Press

14. Harris Z. (2005) Rethinking academic identities in neo-liberal times. Teaching in Higher Education, 10 (4): 421-433

15. Henry FM. (1964) Physical education: An academic discipline. JOHPER, 35 (7): $32-33$

16. Karanauskienė D. (2006) Būsimųjų kūno kultūros ir sporto specialistų identifikacijos su aukštąja mokykla raiška: daktaro disetacija: socialiniai mokslai, edukologija (07S), Vilnius: VPU, Kaunas: LKKA

17. Krishnan A. (2009) What are academic disciplines? Some observations on the disciplinarity vs. interdisciplinarity Debate. NCRM Working Paper. National Centre for Research Methods.

18. McNamara MS. (2010) Where is nursing in academic nursing? Disciplinary discourses, identities and clinical practice: A critical perspective from Ireland. J Clin Nurs, 19: 766-774

19. Miškinis K. (2000) Kūno kultūros ir sporto specialistų rengimo tobulinimas: monografija. Kaunas: LKKA

20. Olsen B. (2008) How reasons for entry into the profession illuminate teacher identity development. Teacher Education Quarterly, 35 (3): 23-40

21. Rastauskienè GJ. (2009) Universiteto kūno kultūros dèstytojo profesinio identiteto raiška. Daktaro disertacija, 07 S, Kaunas: LKKA

22. Renson R. (1989) From physical education to kinanthropology: A quest for academic and professional identity. Quest, 41 (3): 235-256

23. Scheff TJ. (1995) Academic gangs. Crime, Law, and Social Change, 23: 157-162 
24. Squires G. (1992) Interdisciplinarity in higher education in the United Kingdom. European Journal of Education, 27 (3): 201-210

25. Taylor G, Spencer S. (2002) Perspectives on social identity. (eds). UK: Sheffield University Press

26. Traweek S. (1988) Beamtimes and lifetimes. Cambridge \& London: Harvard University Press

27. Wagner H. (2008) Prasmès suradimas tarp neapibrèžtų modernaus gyvenimo modelių ir asmeninès savivertès siekio. Acta Paedagogica Vilnensia, 20: 126-140

28. Weidman JC, Twale DJ, Stein EL. (2001) Graduate and professional students in higher education. ASHE-ERIC Higher Education Report, 28 (3): 40-44

29. Wenger E. (1998) Communities of practice: Learning, meaning and identity. Cambridge: Cambridge University Press

30. Ylijoki Oili-H. (2000) Disciplinary cultures and the moral order of studying: A case-study of four finnish university departments. Higher Education, 39 (3): 339-362

31. Žydžiūnaitė V, Crisafulli S. (2012) Žinių konstravimas aukštojoje mokykloje, kaip prielaida student profesinio tapatumo vystymuisi. Profesinès studijos: teorija ir praktika, 10: 133-141

\section{Correspondence to:}

Edita Vainienè

Lithuanian Sports University

Sporto str. 6, LT-44221 Kaunas

Lithuania

Telepohone: +37068 971925

E-mail: editavaina@gmail.com 